\title{
HUBUNGAN LAMA MENDERITA STROKE DENGAN KEPATUHAN MENJALANI FISIOTERAPI PADA PASIEN STROKE
}

\author{
Maria Agustina Ermi Tri Sulistiyowati \\ Stikes St. Elisabeth Semarang Jl. Kawi Raya No. 11 Semarang \\ Email :ermi.trisulistiyowati@gmail.com
}

\begin{abstract}
ABSTRAK
Perubahan gaya hidup masyarakat telah menyebabkan terjadinya pergeseran pola penyakit di Indonesia. Sejak tahun 2010 penyakit tidak menular memiliki proporsi lebih banyak dibandingkan penyakit menular.Stroke merupakan salah satu penyebab kematian terbesar di dunia.Sebagian besar pasien stroke (70 -80\%) mengalami gangguan gerak berupa kelemahan pada salah satu tubuhnya.Rehabilitasi medis berupa fisioterapi menjadi salah satu pilihan untuk membantu pemulihan pada pasien stroke. Program fisioterapi pada pasien stroke memerlukan waktu yang relatif lama,sehingga diperlukan kepatuhan pasien dalam menjalaninya.Ketidakpatuhan banyak ditemukan pada pasien dengan penyakit kronis, dimana pengobatan membutuhkan jangka waktu yang lama dan tidak memperlihatkan hasil yang cepat terhadap perubahan kesehatan pasien.Penelitian ini bertujuan untuk mengetahui hubungan lama menderita stroke dengan kepatuhan menjalani fisioterapi.Penelitian ini adalah deskriptif analitik dengan pendekatan cross-sectional. Populasi dalam penelitian ini pasien yang menjalani fisioterapi.Sampel diambil dengan tehnik consecutive sampling. Data diolah menggunakan uji fisher. Responden paling banyak berjenis kelamin laki-laki (53,5\%), menderita stroke $>1$ tahun (75\%), dan patuh menjalani fisioterapi (75\%). Hasil uji fisherdidapatkanp value 0 , terdapat hubungan antara lama menderita stroke dengan kepatuhan pasien menjalani fisioterapi
\end{abstract}

Kata kunci :lama menderita stroke; kepatuhan; fisioterapi

\section{THE RELATIONSHIP OF LENGTH OF STROKE AND THE PHYSIOTHERAPY COMPLIANCE IN STROKE PATIENTS}

\begin{abstract}
Changes in people's lifestyles have caused changes in disease patterns in Indonesia. Since 2010 non-communicable diseases have more proportions than infectious diseases. Stroke is one of the biggest causes of death in the world. Most stroke patients (70-80\%) experience movement disorders in the form of weakness in one of their bodies. Medical rehabilitation in the form of physiotherapy is an option to help recovery in stroke patients. Physiotherapy program for stroke patients requires a relatively long time, so that patient compliance is required in living it. Non-compliance is found in patients with chronic diseases, where treatment requires a long period of time and does not show rapid results on changes in patient health. This study was aimed to determine the relationship of long-standing stroke with adherence to undergoing physiotherapy. This research was descriptive analytic with cross-sectional approach. The populations in this study were patients undergoing physiotherapy. Samples were taken by consecutive sampling technique. Data were processed using fisher's test. The most respondents are male (53.5\%), had a stroke> 1 year (75\%), and obediently join physiotherapy program $(75 \%)$. Fisher test results obtained $p$ value 0 , there is a relationship between the length of suffering from stroke with patient compliance undergoing physiotherapy
\end{abstract}

Keywords: long suffered a stroke; physiotherapy; adherence

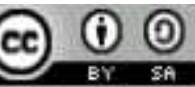

Jurnal SMART Keperawatan is licensed under a Creative Commons Attribution-ShareAlike 4.0 International License 


\section{LATAR BELAKANG}

Perubahan gaya hidup masyarakat telah menyebabkan terjadinya pergeseran pola penyakit di Indonesia. Pada era 1990-an penyebab kematian dan kesakitan terbesar adalah penyakit menular. Sejak tahun 2010 penyakit tidak menular memiliki proporsi lebih banyak dibandingkan penyakit menular. Hal ini dipicu oleh perubahan pola gaya hidup masyarakat yang tidak sehat. Salah satu penyakit tidak menular yang terus mengalami peningkatan adalah stroke (Desy Susilawati,20017).

Stroke merupakan salah satu penyebab kematian terbesar di dunia.Stroke menjadi penyebab kesakitan dan kematian nomor 2 di Eropa dan nomor 3 di Amerika Serikat. Angka kejadian stroke dari tahun ke tahun selalu mengalami peningkatan. Jumlah penderita stroke diperkiran terus meningkat sejalan dengan meningkatnya faktor resiko dan penduduk usia lanjut.

Prevalensi stroke di Indonesia berdasarkan diagnosis tenaga kesehatan sebesar 7 per mil dan yang terdiagnosis tenaga kesehatan atau gejala sebesar 12,1 per mil. Prevalensi Stroke berdasarkan terdiagnosis tenaga kesehatan dan gejala tertinggi terdapat di Sulawesi Selatan $(17,9 \%)$, DI Yogyakarta $(16,9 \%)$, Sulawesi Tengah $(16,6 \%)$, diikuti Jawa Timur sebesar 16 per mil, sedangkan prevalensi stroke di Jawa Tengah sebesar 12,3\% (Kementerian Kesehatan RI, 2013)

Gangguan neurologis pada pasien stroke yang terjadi akibat berhentinya suplai darah ke otak secara mendadak dapat menyebabkan kematian sel - sel pada sebagian area otak. Kerusakan otak pada pasien stroke dapat menimbulkan gangguan penglihatan, bicara, kelumpuhan, koordinasi tubuh, penurunan kemampuan kognitif, kehilangan memori, dan kematian. Sebagian besar pasien stroke ( 70 $80 \%$ ) mengalami gangguan gerak berupa kelemahan pada salah satu tubuhnya (Batticaca,2008).

Rehabilitasi medis berupa fisioterapi menjadi salah satu pilihan untuk membantu pemulihan pada pasien stroke. Fisioterapi membantu mengembangkan, memelihara, memulihkan gerak dan fungsi tubuh pada pasien.Program fisioterapi pada pasien stroke memerlukan waktu yang relatif lama, sehingga diperlukan kesungguhan dalam menjalaninya. Setiap orang yang terlibat dalam program fisioterapi harus bersungguh-sungguh dalam menjalankan program fiisoterapi agardapat mempercepat perbaikan gerak dan fungsi tubuh. Kepatuhan pasien dalam menjalani fisioterapi akan mempengaruhi keberhasilan dari program ini. Ketidakpatuhan menjalani fisioterapi dapat memberikan dampak negatif bagi pasien (Depkes RI,2013;Aprilia,2016)

Saat ini ketidakpatuhan pasien menjadi isu dan masalah serius dikalangan professional kesehatan. Pengembangan riset atauprogram dibidang kesehatan tidak akan ada artinya jika tidak diikuti dengan kepatuhan pasien terhadap pengobatan. Hasil penelitian Cecep ( 2014) tentang hubungan peran keluarga dalam memotivasi pasien pasca stroke dengan kepatuhan penderita mengikuti rehabilitasi di unit rehabilitasi medik rumah sakit stroke nasional Bukittinggi menunjukan bahwa sebagian besar pasien ( $54 \%$ ) tidak patuh menjalani rehabilitasi medik. Penelitian yang dilakukan Wiwik Arianti tentang hubungan pengetahuan pasien tentang stroke dengan kepatuhan menjalani fisioterapi di ruang fisioterapi RSUD Dr. Pirnga di Medan tahun 2016 juga menunjukkan bahwa sebagian besar responden $(65,6 \%)$ tidak patuh menjalani fisioterapi. Ketidakpatuhan banyak ditemukan pada pasien dengan penyakit kronis, dimana pengobatan membutuhkan jangka waktu yang lama dan tidak memperlihatkan hasil yang cepat terhadap perubahan kesehatan pasien.

\section{METODE}

Penelitian ini merupakan penelitian deskriptif analitik dengan pendekatan cross-sectional. Populasi dalam penelitian adalah pasien yang menjalani fisioterapi di Rumah Sakit Umum Daerah Ambarawa. Sampel sebanyak 28 orang diambil dengan tehnik consecutive sampling dengan kriteria :terdaftar di bagian rehabilitasi medik, mengalami kelemahan/kelumpuhan 
anggota gerak bawah/atas, sudah menjalani program fisioterapi selama satu bulan dan memiliki jadwal fisioterapi 3xseminggu. Data diolah dengan menggunakan uji fisher.

HASIL

\section{Karakteristik responden menurut jenis kelamin}

Tabel 1. Karateristik responden menurut jenis kelamin

\begin{tabular}{ccc}
\hline \multicolumn{1}{c}{ Jenis Kelamin } & $\mathrm{N}$ & $\%$ \\
\hline Laki-Laki & 15 & 53,5 \\
Perempuan & 13 & 46,5 \\
\hline \multicolumn{1}{c}{ Total } & 28 & 100 \\
\hline
\end{tabular}

Tabel di atas menunjukkan bahwa responden paling banyak berjenis kelamin laki-laki, yaitu sebanyak 15 orang $(53,5 \%)$

\section{Distribusi lama menderita stroke}

Tabel 2.Distribusi lama menderita stroke

\begin{tabular}{ccc}
\hline Lama Sakit & $\mathrm{n}$ & $\%$ \\
\hline$>1$ tahun & 21 & 75 \\
$<1$ tahun & 7 & 25 \\
\hline Total & 28 & 100
\end{tabular}

Tabel di atas menunjukkan bahwa sebagian besar responden, yaitu 21 (75\%) menderita stroke dalam jangka lama ( $>1$ tahun ).

\section{Distribusi kepatuhan menjalani fisioterapi}

Tabel 3. Distribusi kepatuhan menjalani fisioterapi

\begin{tabular}{lcc}
\hline $\begin{array}{l}\text { Kepatuhan menjalani } \\
\text { fisioterapi }\end{array}$ & $\mathrm{n}$ & $\%$ \\
\hline Patuh & 21 & 75 \\
Tidak patuh & 7 & 25 \\
\hline \multicolumn{1}{c}{ Total } & 28 & 100 \\
\hline
\end{tabular}

Tabel di atas menunjukkan bahwa dari 28 responden yang patuh menjalani fisioterapi sebanyak 21 responden (75\%)

\section{Hubungan lama menderita stroke dengan kepatuhan menjalani fisioterapi}

Tabel 4. Hubungan lama menderita stroke dengan kepatuhan menjalani fisioterapi

\begin{tabular}{cccccccc}
\hline \multirow{2}{*}{$\begin{array}{c}\text { Lama } \\
\text { menderita } \\
\text { stroke }\end{array}$} & \multicolumn{6}{c}{ Kepatuhan } & \\
\cline { 2 - 7 } & Patuh & \multicolumn{4}{c}{$\begin{array}{c}\text { Tidak } \\
\text { Patuh }\end{array}$} & Total & $\begin{array}{c}\mathrm{p} \\
\text { value }\end{array}$ \\
\cline { 2 - 7 } & $\mathrm{n}$ & $\%$ & $\mathrm{n}$ & $\%$ & $\mathrm{n}$ & $\%$ & \\
\hline$>1$ tahun & 19 & 68 & 2 & 7 & 21 & 75 & 0,004 \\
$<1$ tahun & 2 & 7 & 5 & 18 & 7 & 25 & \\
\hline Total & 21 & 75 & 7 & 25 & 28 & 100 & \\
\hline
\end{tabular}

Tabel di atas menunjukkan hubungan antara lama menderita stroke dengan kepatuhan menjalani fisioterapi.Terdapat 19 responden (68\%) yang menderita stroke $>1$ tahun patuh menjalani fisioterapi dan 2 responden (7 \%) tidak patuh menjalani fiisoterapi. Sedangkan responden yang menderita stroke $<1$ tahun yang patuh menjani fisioterapi sebanyak 2 responden (7\%) dan yang tidak patuh menjalani fisioterapi sebanyak 5 responden (7\%). Analisa data dilakukan dengan menggunakan Uji fisher dengan hasil nilai $p$ value $0,004(<0,05)$ yang berarti $\mathrm{H} 0$ ditolak dan $\mathrm{H} 1$ diterima sehingga dapat disimpulkan terdapat hubungan antara lama menderita stroke dengan kepatuhan pasien menjalani fisioterapi.

\section{PEMBAHASAN}

Stroke merupakan ganguan syaraf permanen akibat terganggunya peredaran darah otak yang terjadi secara mendadak dan bersifat progresif. Jenis kelamin merupakan salah satu faktor resiko stroke yang tidak dapat diubah. Dalam penelitian ini responden paling banyak berjenis kelamin laki-laki, yaitu sebanyak 15 orang (53,5\%). Laki-laki dua kali lebih berisiko terkena stroke dibandingkan perempuan (Mulyatsih,2010).Hasil penelitian ini sejalan dengan penelitian yang dilakukan oleh Irma tentang hubungan karakteristik pasien stroke dan dukungan keluarga dengan kepatuhan menjalani rehabilitasi. Hasil penelitian Irma menunjukkan bahwa karakteristik pasien stroke sebagian besar adalah laki - laki (Irma,2015). Laki-laki memiliki kecenderungan lebih besar untuk terkena stroke dibandingkan dengan wanita pada usia dewasa awal, dengan perbandingan 2:1. Walaupun laki - laki lebih rawan daripada perempuan pada usia muda, tetapi kejadian stroke pada perempuan akan meningkat setelah usia mencapai menopause. Laki-laki memiliki hormon testoteron yang bisa meningkatkan kadar LDL darah. Kadar LDL yang tinggi akan meningkatkan kadar kolesterol dalam darah, sehinga akan meningkatkan risiko penyakit stroke. Sedangkan perempuan dilindungi oleh hormon esterogen yang meningkatkan $\mathrm{HDL}$ yang berperan untuk 
pencegahan terjadinya proses aterosklerosis. (Burhanuddin, 2012).

Proses penyembuhan stroke memakan waktu yang realatif lama. Sebagian besar responden mengalami stroke $>1$ tahun (75\%). Beberapa teori mengatakan bahwa pasien yang mengalami sakit dalam kurun waktu yang lama akan dapat merasa bosan, putus asa terhadap manfaat terapi, dan biaya yang harus dikeluarkan secara terus menerus akan menurunkan motivasi pasien untuk patuh terhadap program terapi. Hasil penelitian menunjukkan hal yang berbeda, pasien yang menderita stroke jangka lama ( $>1$ tahun )lebih banyak (75\%), yang patuh dibandingkan yang menderita stroke jangka pendek ( $<1$ tahun). Hal ini dapat disebabkan karena terdapat banyak faktor yang dapat mempengaruhi kepatuhan seseorang dalam menjalani program terapi. Tingkat pengetahuan, motivasi, dukungan petugas dan dukungan keluarga mempengaruhi kepatuhan dalam pengobatan (Gede Wahyu Pratama, 2015)

Berdasarkan hasil uji fisher didapatkan $p$ value $0,004(p<0,05)$ yang berarti $\mathrm{HO}$ ditolak dan $\mathrm{H} 1$ diterima sehingga dapat disimpulkan ada hubungan yang bermakna antara lama menderita stroke dengan kepatuhan pasien stroke menjalani fisioterapi di Instalasi Rehabilitasi Medik RSUD Ambarawa. Kepatuhan menjalani terapi adalah suatu perilaku positif yang diperlihatkan seseorang dalam menjalankan program terapi.Rehabilitasi pasien pasca stroke sangat bermanfaat untuk mempercepat pemulihan kecacatan yang dialami pasien (Lanny Lingga,2013).

Rehabilitasi bertujuan untuk mencegah komplikasi, meminimalkan gangguan, dan memaksimalkan fungsi organ. Prioritas rehabilitasi stroke dini adalah pencegahan stroke sekunder, managemen dan pencegahan penyakit penyerta serta komplikasi.Rehabilitasi berupa fisioterapi pada pasien stroke dilakukan dengan memberikan latihan-latihan pada pasien baik dengan alat bantu atau tidak, sesuai dengan kemampuan atau kondisi penyakitnya. Kepatuhan pasien merupakan faktor penting dalam keberhasilan terapi, terutama pada pasien dengan penyakit kronik, seperti stroke. Kelengkapan menjalani program fisioterapi sangat penting untuk pemulihan kondisi pasien post stroke. Kelengkapan program fisioterapi yang baik akan membantu pasien dalam memenuhi kebutuhan sehari-harinya, sehingga pasien dapat memiliki kepercayaan diri dalam mengerjakan tugas-tugasnya sendiri tanpa bantuan orang lain (Tanti,2015) Ketidakpatuhan pasien dalam pengobatan maupun terapi dapat memberikan dampak negatif bagi pasien tersebut. Ketidakpatuhan pengobatan dan terapi pada pasien stroke dapat menyebabkan terjadinya stroke ulang yang dapat lebih parah daripada stroke sebelumnya (Irma,2015).

\section{KESIMPULAN DAN SARAN}

Responden paling banyak berjenis kelamin lakilaki (53,5\%), menderita stroke > 1 tahun (75\%), danpatuh menjalani fisioterapi (75\%). Hasil uji fisher didapatkan $p$ value0,004,terdapat hubungan antara lama menderita stroke dengan kepatuhan pasien menjalani fisioterapi. Diharapkan pasien pasca stroke patuh menjalani program fisioterapi.

\section{REFERENSI}

Aprilia Wahyu (2016). Hubungan Dukungan Keluarga Dengan Motivasi Pada Pasien Pasca Stroke Untuk Menjalani Fisioterapi Di RSUD Wilayah Kabupaten Semarang.

Badan Penelitian dan Pengembangan Kesehatan Kementerian Kesehatan RI (2013). Riset Kesehatan Dasar.

Burhanuddin et al.(2013). Faktor Risiko Kejadian Stroke Pada Dewasa Awal (18-40 Tahun) di Kota Makassar Tahun 2010-2012. Jurnal MKMI. Available from :www.repository.unhas.ac.id

Cecep et al.(2015). Hubungan Peran Keluarga dalam Memotivasi Pasien Pasca Stroke Dengan Kepatuhan Penderita Mengikuti Rehabilitasi Di Unit Rehabilitasi Medik Rumah Sakit Stroke Nasional Bukittinggi: Jurnal Kesehatan STIKes Prima Nusantara Bukittinggi, Vol.6 No 1 Januari 2015

Departemen Kesehatan RI. Keputusan Menteri Kesehatan Republik Indonesia Nomor 376/MENKES/SK/III/2007 Tentang Standar Profesi Fisioterapi. Available from http://www.pdpersi.co.id/peraturan/kepmenkes/k mk3762007.pdf

Departemen Kesehatan RI.(2007) Keputusan Menteri Kesehatan Republik Indonesia Nomor 376/MENKES/SK/III/2007 Tentang Standar Profesi Fisioterapi. 
Irma Okta Wardhani et.al.(2015).Hubungan Antara Karakteristik Pasien Stroke dan Dukungan Keluarga Dengan Kepatuhan Menjalani Rehabilitasi.Jurnal Berkala Epidemiologi, Vol. 3, No. 1 Januari 2015: 24-34

Lanny Lingga.(2013).All about Stroke.PT Elex Media Komputindo.Jakarta

Mulyatsih.(20100. Stroke Petunjuk Perawatan Pasien Pasca Stroke Di Rumah. Jakarta: FKUI

Susilawati.Indonesia Hadapi Pergeseran Pola Penyakit.Available from https://www.republika.co.id/berita/gaya- hidup/info-sehat/17/04/28/op3vc0335-indonesiahadapi-pergeseran-pola-penyakit

Tanty.(2015). Hubungan Program Fisioterapi Dengan Tingkat Kemandirian Pasien Post Stroke.Jurnal Keperawatan.Vol. VIII No 3 Desember 2015

Wiwik et al.(2018).Hubungan pengetahuan pasien tentang stroke dengan kepatuhan menjalani fisioterapi di ruang fisioterapi RSUD Dr.Pirngadi Medan: Jurnal IImiah PANNMEDVol. 13 No.1 Mei - Agustus 2018 